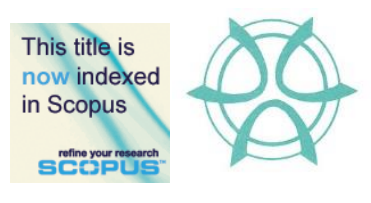

PLANNING MALAYSIA:

Journal of the Malaysian Institute of Planners

VOLUME 16 ISSUE 1 (2018), Page 314 - 323

\title{
XRD AND XRF ANALYSIS OF THE ANCIENT BRICKS FROM CANDI KAMPUNG BARU, KEDAH
}

\author{
Zuliskandar Ramli', Muhammad Nu'man Mohd Nasir' , Abdul Latif Samian ${ }^{3}$, Nor \\ Zalina Harun ${ }^{4}$, Mohd Shamsul Bahari Abdul Hadi ${ }^{5}$, Nuratikah Abu Bakar ${ }^{6}$ \& Nur \\ Sarahah Mohd Supian ${ }^{7}$ \\ ${ }^{1-7}$ Institute of The Malay World and Civilization \\ THE NATIONAL UNIVERSITY OF MALAYSIA
}

\begin{abstract}
XRD and XRF analysis on the ancient bricks were conducted to identify whether the raw materials to produce the bricks originate from the site. Candi Kampung Baru is recorded as one of the temple that used bricks as the main construction material. This site is suggested to be built between the 8th to 10th centuries AD based on the size of the bricks and imported ceramics associated with the structure. The position of this candi that is facing to the north is a major indication that the candi in Kampung Baru Site is one of the many Buddhist candis that have been found in Bujang Valley. This study used X-Ray Fluorescence (XRF) and XRay Diffraction (XRD) analysis techniques to identify the composition of the major and trace elements and minerals found in the bricks. The results of the analysis on the ancient brick of Candi Kampung Baru revealed that the mineral content contained in the brick samples consists of quartz, muscovite, microcline and sanidine. Minerals found suggest that open burning technique was used during the brick making process with the local raw clay sources were used to produce the bricks. The results therefore implied that the participation of the local communities in Old Kedah Kingdom contributed to the prosperity of this region.
\end{abstract}

Keyword: x-ray fluorescence (XRF), x-ray diffraction (XRD), candi Kampung Baru, Bujang Valley, old Kedah kingdom 
PLANNING MALAYSIA

Journal of the Malaysia Institute of Planners (2018)

\section{INTRODUCTION}

The Kampung Baru site was discovered during the Muda River exploration work which was conducted in 2010 until 2011 by a group of researchers from The National University of Malaysia (Ramli \& Nik Abdul Rahman, 2012). This site is located on the bank of Muda River in Kampung Baru, Kota Kuala Muda, Kedah and the distance between this site and the Muda River is about 100 metres and the archaeological excavations that have been carried out on this site have also found various types of artefacts such as earthenware, glass, metal and other ceramics such as c'hing-pai and celadon (Mohd Nasir, Ramli, \& Hassan, 2017).

The study of the ancient brick from the candi's found in Kedah has formerly been carried out by scholars. However, there is a contradiction between scholars and researchers about the Old Kedah candi's builders and the sources of building materials besides each one of them has their own arguments and evidence. Similarly, the source of raw materials used to build a temple at the Kampung Baru Site is still unknown, therefore, the scientific analysis of the ancient brick at Kampung Baru Candi is necessary to identify the composition of the brick. XRF and XRD analysis have also provided new data on the origin and technology of prehistoric pottery manufacturing in Malaysia (Treloar, 1978; Chia, 1997), glass beads (Ramli, Nik Abdul Rahman, \& Samian, 2011; Ramli, Abdul Rahman, Hussin, Sayed Hasan, \& Mohamed Dali, 2017), bronze drum (Jusoh, Sauman, Abdul Rahman, \& Ramli, 2012), as well as ancient bricks (Ramli, 2012; Ramli, Nik Abdul Rahman, Jusoh, \& Hussein, 2012; Ramli et al., 2013; Sabtu, Mahat, Mohd Amin, Price, \& Bradley, 2015). Whereas Yahaya, Hussein, Ramli, and Zakaria (2005) conducted a physical analysis on the bricks found in Kuala Muda, Kedah. The study focused on the brick pressure force tests and also by looking at the physical size of the brick. Even closer study has also been conducted at the Panggung Drama Building, Kuala Lumpur which combines the analysis of the content and physical composition of the building materials (Hussein, Ramli, \& Yahaya, 2004).

The Kampung Baru site located near Kampung Sungai Mas site was the centre of government and the port of Old Kedah. The study on the Kampung Sungai Mas site was initiated in 1979 by Jane Allen and Jan Wisseman Christe in collaboration with the Bujang Valley Archaeological Museum and the Department of Geography, University of Malaya to conduct research on "Trade transportation and tributaries: exchange, agriculture and settlement distribution in early historic-period Kedah, Malaysia". Subsequently in 1980 a team of researchers from Universiti Kebangsaan Malaysia led by Nik Hassan Shuhaimi Nik Abd. Rahman has conducted an archaeological survey at the Kampung Sungai Mas Site (Nik Abdul Rahman \& Mohd Yatim, 1992). In 1981, Nik Hassan Suhaimi and his team conduct the first trial excavation at the Site 33 (Abdullah, 2013). Drawing to this activity, in 1985, another site identified as Kampung Sungai Mas (Site 32/34) was selected for the 2nd Intra-ASEAN Archaeological 
Zuliskandar Ramli, Muhammad Nu'man, Abdul Latif, Nor Zalina, Mohd Shamsul Bahari, Nuratikah \& Nur Sarahah $X R D$ and XRF Analysis of the Ancient Bricks from Candi Kampung Baru, Kedah

Excavation and Conservation project of Bujang Valley, Kedah, Malaysia in 19858. Discovery of foreign ceramics, building materials, glass, pottery, beads, and stone have become significant findings at that time.

Compositional analysis of the ancient brick used in the construction of the candi in Kampung Baru is carried out in order to determine the mineral content besides the major and trace elements contained in the brick samples. Data obtained from the subsequent brick analysis will be compared with the composition data of clay material around the Bujang Valley area, Kedah. It is important to carry out material composition analysis of the ancient bricks of this site because the analysis can determine the raw materials used to produce the bricks whether it locally made or not, because there are scholars who think that the candis found in Old Kedah was built by the Indian traders (Jacq-Hergoualc'h, 1992; Treloar, 1978; Wheatley, 1964). Besides that, the bricks that were found at this site also have different sizes and shapes (refer figure 1 until 4 below).

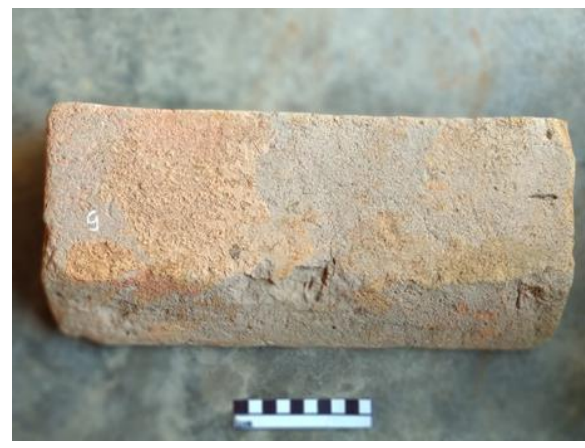

Figure 1: Brick 5 (top view)

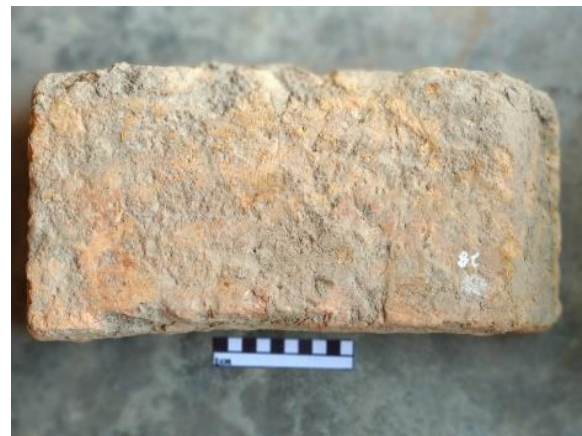

Figure 3: Brick 28 (top view)

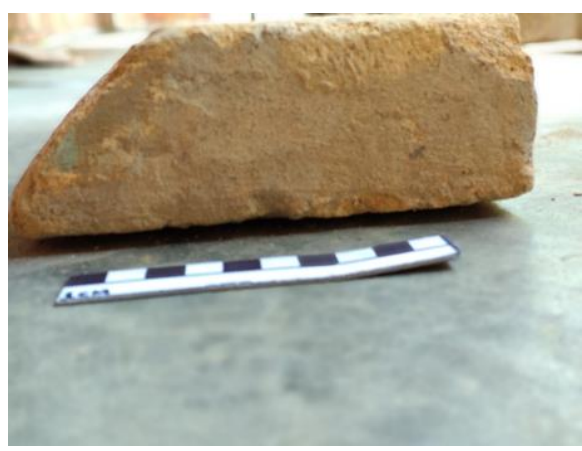

Figure 2: Brick 5 (side view)

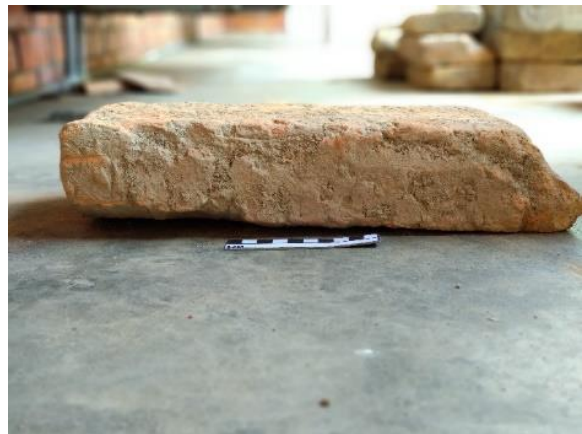

Figure 4: Brick 28 (side view)

\section{METHODOLOGY}

A total of 20 brick samples were taken from the Candi Kampung Baru Site and then taken to the lab for cleaning and labelled with the names $\mathrm{KB} 1, \mathrm{~KB} 2, \mathrm{~KB} 3$, KB 4, KB 5, KB 6, KB 7, KB 8, KB 9, KB 10, KB 11, KB 12, KB 13, KB 14, 
PLANNING MALAYSIA

Journal of the Malaysia Institute of Planners (2018)

KB 15, KB 16, KB 17, KB 18, KB 19, and KB 20. The analysis was conducted to determine the mineral content in the ancient brick samples. Samples weighing $0.4 \mathrm{~g}$ were refined and heated up for one hour at a temperature of $105 \mathrm{o} \mathrm{C}$ and mixed until homogenous with the flux powder of a type of Spectroflux 110 (product of Johnson and Mathey). These mixtures were baked for one hour in a furnace with a temperature of $1100 \mathrm{o}$. The homogenous molten was moulded in a container and cooled gradually into pieces of fused glass with a thickness of $2 \mathrm{~mm}$ and a diameter of $32 \mathrm{~mm}$. The samples were 1:10 dilution. Samples in the formed of fused glass were prepared for analysis of major elements such as $\mathrm{Si}$, $\mathrm{Na}, \mathrm{K}, \mathrm{Ca}, \mathrm{Fe}, \mathrm{Al}, \mathrm{Ti}, \mathrm{Mn}$, and $\mathrm{Mg}$. Pressed pallet samples were prepared for analysis of trace elements such as $\mathrm{As}, \mathrm{Ba}, \mathrm{Ce}, \mathrm{Cr}, \mathrm{Cu}, \mathrm{Ga}, \mathrm{Ni}, \mathrm{Pb}, \mathrm{Rb}, \mathrm{Sr}, \mathrm{Th}, \mathrm{V}$, $\mathrm{Zn}$, and $\mathrm{Zr}$. These samples were prepared by mixing $1.0 \mathrm{~g}$ of samples together with $6.0 \mathrm{~g}$ of boric acid powder and then the pressure of 20 psi was applied by using hydraulic pressure equipment. The samples of the fused pallet and pressed pallets were then analysed by using the Philips PW1480 equipment. Samples in the form of very fine powder were put into the pellets (sample holder) and then analysed by using the X-ray Diffraction instrument (D500 Diffract meter SIEMEN).

A scatter plot diagram of $\mathrm{MgO}$ versus $\mathrm{TiO} 2$ and lead versus copper was then performed to demonstrate the differences among the group and analysed using Microsoft Excel software. The main purpose is to see the distribution of the samples in the group and subsequently to compare with the clay elements. The applicability of the analytical methods for the multi-elemental analysis by XRF of the glass beads is evaluated by the analysis of certified reference material, 315 Fire Brick (Calibration: G-FBVac28 mm) for major elements and certified reference materials, SY-2 (Calibration: Trace Element P-20) for trace elements. The CRM was also used as the quality control material of the analytical procedure.

\section{RESULTS AND DISCUSSION}

The results of the analysis showed that the mineral content contained in the brick samples consists of quartz, muscovite, microcline, sanidine. Besides, there was no kaolinite mineral in the brick sample but based on the physical appearance it was found that the brick did not have complete oxidation (refer Table 1). This showed that open burning techniques were used during the bricks making process. The burning temperature of the brick samples from this site was believed to be between $600^{\circ} \mathrm{C}$ to $800^{\circ} \mathrm{C}$.

The major element contents contained in the ancient brick samples of Kampung Baru Candi in detail can be referred to Table 2. The analysis showed that the ancient brick samples contained percentage of dry weight quartz elements between $70.00 \%$ to $83.66 \%$. The percentage of dry weight of titanium was between $0.07 \%$ to $0.96 \%$. The iron element contained a dry weight percentage of 
Zuliskandar Ramli, Muhammad Nu'man, Abdul Latif, Nor Zalina, Mohd Shamsul Bahari, Nuratikah \& Nur Sarahah $X R D$ and XRF Analysis of the Ancient Bricks from Candi Kampung Baru, Kedah

$1.81 \%$ to $3.68 \%$. The percentage of dry weight of aluminium was between $13.95 \%$ and $22.54 \%$. The manganese element contained a dry weight percentage of $0.01 \%$ to $0.04 \%$ while the calcium elements contained a dry weight percentage of $0.05 \%$ to $0.34 \%$. The percentage of dry weight of magnesium and sodium was between $0.18 \%$ to $0.99 \%$ and $0.07 \%$ to $0.42 \%$. Potassium and phosphorus elements contained dry weight percentage ranging from $0.46 \%$ to $2.15 \%$ and $0.11 \%$ to $0.85 \%$.

Elements such as silica, aluminium, and iron are elements containing a high percentage of dry weight for brick samples at Kampung Baru Candi. The percentage graph of the dry weight of $\mathrm{SiO} 2$ and $\mathrm{Al} 2 \mathrm{O} 3$ (refer Figure 5) and also the percentage graph of the dry weight of $\mathrm{MgO}$ and $\mathrm{TiO} 2$ (refer Figure 6) for brick samples from Candi Kampung Baru and clay in Bujang Valley have been plotted to observe the results of the comparison between the samples of brick and clay based on its primary source. Based on the graphs, the composition of the major elements of the brick sample of Kampung Baru Candi was found to be similar to the composition of the major elements of clay in the Bujang Valley. These raw materials were obtained from the Sungai Muda basin, the Bujang River basin and the surrounding Mukim Merbok and Mukim Bujang. In fact, this study also found that the raw materials used at this site were obtained from various sources compared to the raw material used to produce bricks candi in Kampung Sungai Mas (Site 32/34) that only used raw materials found in Muda River and Bujang River.

Table 1: Minerals content in bricks sample from Candi Kampung Baru

\begin{tabular}{|c|c|c|}
\hline Site & Sample & Mineral Content \\
\hline $\begin{array}{l}\text { Kg. Baru, Kota } \\
\text { Kuala Muda, Kedah }\end{array}$ & $\begin{array}{l}\text { KB } 2 \\
\text { KB } 3 \\
\text { KB } 4 \\
\text { KB } 5\end{array}$ & $\begin{array}{l}\mathrm{SiO}_{2} \mathrm{Quartz} \\
\mathrm{KAl}_{2} \mathrm{Si}_{3} \mathrm{AlO}_{10}(\mathrm{OH})_{2} \text { Muscovite } 1 \mathrm{M} \\
\mathrm{K}_{2} \mathrm{O} . \mathrm{Al}_{2} \mathrm{O}_{3.6} \mathrm{SiO}_{2} \text { Microline } \\
\mathrm{SiO}_{2} \text { Quartz } \\
\mathrm{KAl}_{2} \mathrm{Si}_{3} \mathrm{AlO}_{10}(\mathrm{OH})_{2} \text { Muscovite } 1 \mathrm{M} \\
\mathrm{SiO}_{2} \text { Quartz } \\
\mathrm{KAl}_{2} \mathrm{Si}_{3} \mathrm{AlO}_{10}(\mathrm{OH})_{2} \text { Muscovite } 1 \mathrm{M} \\
\mathrm{KAlSi}_{3} \mathrm{O}_{8} \mathrm{Microcline} \\
\mathrm{SiO}_{2} \mathrm{Quartz} \\
\mathrm{KAl}_{2} \mathrm{Si}_{3} \mathrm{AlO}_{10}(\mathrm{OH})_{2} \text { Muscovite } 1 \mathrm{M} \\
\mathrm{SiO}_{2} \text { Quartz } \\
\mathrm{KAl}_{2} \mathrm{Si}_{3} \mathrm{AlO}_{10}(\mathrm{OH})_{2} \text { Muscovite } 1 \mathrm{M} \\
\mathrm{KAlSi}_{3} \mathrm{O}_{8} \mathrm{Microcline} \\
\mathrm{SiO}_{2} \mathrm{Quartz} \\
\mathrm{KAl}_{2} \mathrm{Si}_{3} \mathrm{AlO}_{10}(\mathrm{OH})_{2} \text { Muscovite } 1 \mathrm{M} \\
\mathrm{K}_{2} \mathrm{O}_{2} \mathrm{Al}_{2} \mathrm{O}_{3.6} \mathrm{SiO}_{2} \text { Microline } \\
\mathrm{SiO}_{2} \text { Quartz } \\
\mathrm{KAl}_{2} \mathrm{Si}_{3} \mathrm{AlO}_{10}(\mathrm{OH})_{2} \text { Muscovite } 1 \mathrm{M} \\
\mathrm{KAlSi}_{3} \mathrm{O}_{8} \mathrm{Microcline} \\
\mathrm{SiO}_{2} \text { Quartz }\end{array}$ \\
\hline
\end{tabular}




\begin{tabular}{|c|c|}
\hline \multirow{4}{*}{ KB 9} & $\mathrm{KAl}_{2} \mathrm{Si}_{3} \mathrm{AlO}_{10}(\mathrm{OH})_{2}$ Muscovite $1 \mathrm{M}$ \\
\hline & $\mathrm{SiO}_{2}$ Quartz \\
\hline & $\mathrm{KAl}_{2} \mathrm{Si}_{3} \mathrm{AlO}_{10}(\mathrm{OH})_{2}$ Muscovite $1 \mathrm{M}$ \\
\hline & $\mathrm{KAlSi}_{3} \mathrm{O}_{8} \mathrm{Microcline}$ \\
\hline \multirow[t]{3}{*}{ KB 10} & $\mathrm{SiO}_{2}$ Quartz \\
\hline & $\mathrm{KAl}_{2} \mathrm{Si}_{3} \mathrm{AlO}_{10}(\mathrm{OH})_{2}$ Muscovite $1 \mathrm{M}$ \\
\hline & $\mathrm{KAlSi}_{3} \mathrm{O}_{8}$ Microcline \\
\hline \multirow[t]{3}{*}{ KB 11} & $\mathrm{SiO}_{2}$ Quartz \\
\hline & $\mathrm{KAl}_{2} \mathrm{Si}_{3} \mathrm{AlO}_{10}(\mathrm{OH})_{2}$ Muscovite $1 \mathrm{M}$ \\
\hline & $\mathrm{K}_{0.47} \mathrm{Na}_{0.43} \mathrm{Ca}_{0.10} \mathrm{Al}_{1.1} \mathrm{Si}_{2.9} \mathrm{O}_{8}$ Sanidine \\
\hline \multirow[t]{2}{*}{ KB 12} & $\mathrm{SiO}_{2}$ Quartz \\
\hline & $\mathrm{KAl}_{2} \mathrm{Si}_{3} \mathrm{AlO}_{10}(\mathrm{OH})_{2}$ Muscovite $1 \mathrm{M}$ \\
\hline \multirow[t]{3}{*}{ KB 13} & $\mathrm{SiO}_{2}$ Quartz \\
\hline & $\mathrm{KAl}_{2} \mathrm{Si}_{3} \mathrm{AlO}_{10}(\mathrm{OH})_{2}$ Muscovite $1 \mathrm{M}$ \\
\hline & $\mathrm{KAlSi}_{3} \mathrm{O}_{8}$ Microcline \\
\hline \multirow[t]{2}{*}{ KB 14} & $\mathrm{SiO}_{2}$ Quartz \\
\hline & $\mathrm{KAl}_{2} \mathrm{Si}_{3} \mathrm{AlO}_{10}(\mathrm{OH})_{2}$ Muscovite $1 \mathrm{M}$ \\
\hline \multirow[t]{2}{*}{ KB 15} & $\mathrm{SiO}_{2}$ Quartz \\
\hline & $\mathrm{KAl}_{2} \mathrm{Si}_{3} \mathrm{AlO}_{10}(\mathrm{OH})_{2}$ Muscovite $1 \mathrm{M}$ \\
\hline \multirow[t]{3}{*}{ KB 16} & $\mathrm{SiO}_{2}$ Quartz \\
\hline & $\mathrm{KAl}_{2} \mathrm{Si}_{3} \mathrm{AlO}_{10}(\mathrm{OH})_{2}$ Muscovite $1 \mathrm{M}$ \\
\hline & $\mathrm{KAlSi}_{3} \mathrm{O}_{8}$ Microcline \\
\hline \multirow[t]{2}{*}{ KB 17} & $\mathrm{SiO}_{2}$ Quartz \\
\hline & $\mathrm{KAl}_{2} \mathrm{Si}_{3} \mathrm{AlO}_{10}(\mathrm{OH})_{2}$ Muscovite $1 \mathrm{M}$ \\
\hline \multirow[t]{2}{*}{ KB 18} & $\mathrm{SiO}_{2}$ Quartz \\
\hline & $\mathrm{KAl}_{2} \mathrm{Si}_{3} \mathrm{AlO}_{10}(\mathrm{OH})_{2}$ Muscovite $1 \mathrm{M}$ \\
\hline \multirow[t]{3}{*}{ KB 19} & $\mathrm{SiO}_{2}$ Quartz \\
\hline & $\mathrm{KAl}_{2} \mathrm{Si}_{3} \mathrm{AlO}_{10}(\mathrm{OH})_{2}$ Muscovite $1 \mathrm{M}$ \\
\hline & $\mathrm{KAlSi}_{3} \mathrm{O}_{8}$ Microcline \\
\hline \multirow[t]{2}{*}{ KB 20} & $\mathrm{SiO}_{2}$ Quartz \\
\hline & $\mathrm{KAl}_{2} \mathrm{Si}_{3} \mathrm{AlO}_{10}(\mathrm{OH})_{2}$ Muscovite $1 \mathrm{M}$ \\
\hline
\end{tabular}

Table 2: Dry Weight (\%) of major elements in Candi Kampung Baru Brick Samples

\begin{tabular}{|c|c|c|c|c|c|c|c|c|c|c|}
\hline \multirow{2}{*}{ Sample } & \multicolumn{10}{|c|}{ Dry Weight (\%) } \\
\hline & $\mathbf{S i}$ & $\mathbf{T i}$ & $\mathbf{F e}$ & Al & Mn & $\mathbf{C a}$ & Mg & $\mathbf{N a}$ & $\mathbf{K}$ & $\mathrm{P}_{2} \mathrm{O}_{3}$ \\
\hline KB 1 & 70.00 & 0.49 & 3.21 & 13.95 & 0.02 & 0.14 & 0.44 & 0.19 & 1.40 & 0.22 \\
\hline KB 2 & 72.83 & 0.93 & 3.37 & 21.47 & 0.01 & 0.05 & 0.20 & 0.10 & 0.73 & 0.15 \\
\hline KB 3 & 77.96 & 0.42 & 3.05 & 12.98 & 0.03 & 0.25 & 0.90 & 0.42 & 1.96 & 0.45 \\
\hline KB 4 & 72.97 & 0.96 & 2.85 & 21.76 & 0.01 & 0.04 & 0.22 & 0.09 & 0.72 & 0.12 \\
\hline KB 5 & 76.81 & 0.52 & 3.07 & 14.14 & 0.04 & 0.30 & 0.98 & 0.19 & 1.62 & 0.28 \\
\hline KB 6 & 73.86 & 0.53 & 3.27 & 16.62 & 0.02 & 0.30 & 0.99 & 0.31 & 2.12 & 0.85 \\
\hline KB 7 & 75.08 & 0.54 & 3.68 & 16.06 & 0.02 & 0.30 & 0.84 & 0.25 & 1.96 & 0.32 \\
\hline KB 8 & 75.62 & 0.70 & 1.81 & 20.33 & 0.01 & 0.03 & 0.18 & 0.07 & 0.58 & 0.13 \\
\hline KB 9 & 76.05 & 0.46 & 2.77 & 14.72 & 0.02 & 0.29 & 0.80 & 0.28 & 1.30 & 0.38 \\
\hline KB 10 & 76.59 & 0.49 & 3.04 & 14.43 & 0.02 & 0.25 & 0.97 & 0.27 & 1.73 & 0.33 \\
\hline KB 11 & 76.58 & 0.49 & 2.92 & 15.07 & 0.03 & 0.24 & 0.67 & 0.32 & 1.93 & 0.61 \\
\hline
\end{tabular}


Zuliskandar Ramli, Muhammad Nu'man, Abdul Latif, Nor Zalina, Mohd Shamsul Bahari, Nuratikah \& Nur Sarahah $X R D$ and XRF Analysis of the Ancient Bricks from Candi Kampung Baru, Kedah

\begin{tabular}{lllllllllll} 
KB 12 & 73.88 & 0.80 & 2.49 & 21.41 & 0.01 & 0.09 & 0.22 & 0.11 & 0.68 & 0.14 \\
KB 13 & 74.94 & 0.51 & 3.31 & 15.14 & 0.04 & 0.34 & 0.86 & 0.51 & 2.15 & 0.44 \\
KB 14 & 83.66 & 0.07 & 1.93 & 21.20 & 0.01 & 0.04 & 0.28 & 0.07 & 0.46 & 0.11 \\
KB 15 & 73.27 & 0.68 & 3.50 & 18.97 & 0.01 & 0.10 & 0.59 & 0.20 & 0.83 & 0.34 \\
KB 16 & 71.40 & 0.93 & 3.59 & 22.51 & 0.02 & 0.09 & 0.21 & 0.11 & 0.80 & 0.28 \\
KB 17 & 73.80 & 0.95 & 2.82 & 20.48 & 0.01 & 0.07 & 0.26 & 0.10 & 0.58 & 0.19 \\
KB 18 & 71.72 & 0.91 & 3.40 & 22.54 & 0.01 & 0.05 & 0.21 & 0.08 & 0.74 & 0.13 \\
KB 19 & 76.75 & 0.51 & 3.71 & 14.5 & 0.02 & 0.24 & 01.01 & 0.24 & 1.62 & 0.29 \\
KB 20 & 77.22 & 0.62 & 1.72 & 18.65 & 0.01 & 0.03 & 0.20 & 0.07 & 0.62 & 0.14 \\
\hline
\end{tabular}

The content of trace elements (Table 3) showed the content of more than $100 \mathrm{ppm}$ for the elements such as barium, cerium, chromium, vanadium, and zircon. Other elements were quite low concentration namely less than $100 \mathrm{ppm}$. The barium element content was between $638 \mathrm{ppm}$ to $835 \mathrm{ppm}$ while the cerium was between $468 \mathrm{ppm}$ to $625 \mathrm{ppm}$. The content of rubidium and chromium elements was between $56 \mathrm{ppm}$ to $205 \mathrm{ppm}$ and $67 \mathrm{ppm}$ to $111 \mathrm{ppm}$ while vanadium and zircon elements had a concentration between $79 \mathrm{ppm}$ to $140 \mathrm{ppm}$ and $165 \mathrm{ppm}$ to $430 \mathrm{ppm}$. Figure 7 is a graph plotted to see the distribution of copper elements against the lead to brick samples at Kampung Baru Temple where the concentration of the two elements was between $14 \mathrm{ppm}$ to $20 \mathrm{ppm}$ and $41 \mathrm{ppm}$ and $57 \mathrm{ppm}$. The result showed that the raw material used to make the brick is a local raw material.

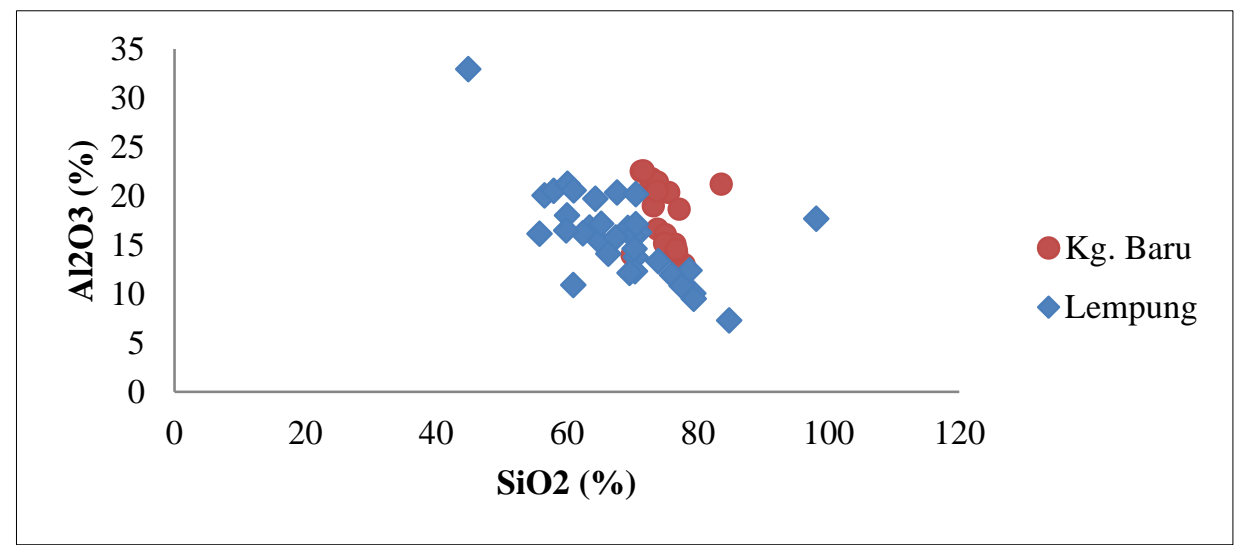

Figure 5: Scatter plot of $\mathrm{SiO}_{2}$ and $\mathrm{Al}_{2} \mathrm{O}_{3}$ 
PLANNING MALAYSIA

Journal of the Malaysia Institute of Planners (2018)

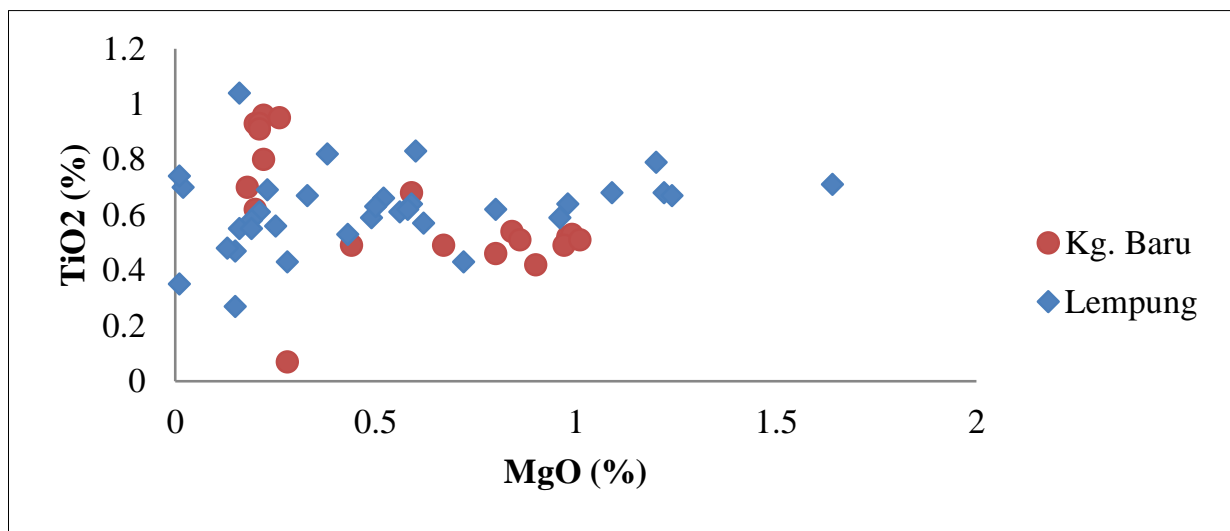

Figure 6: Scatter plot of $\mathrm{MgO}$ and $\mathrm{TiO} 2$

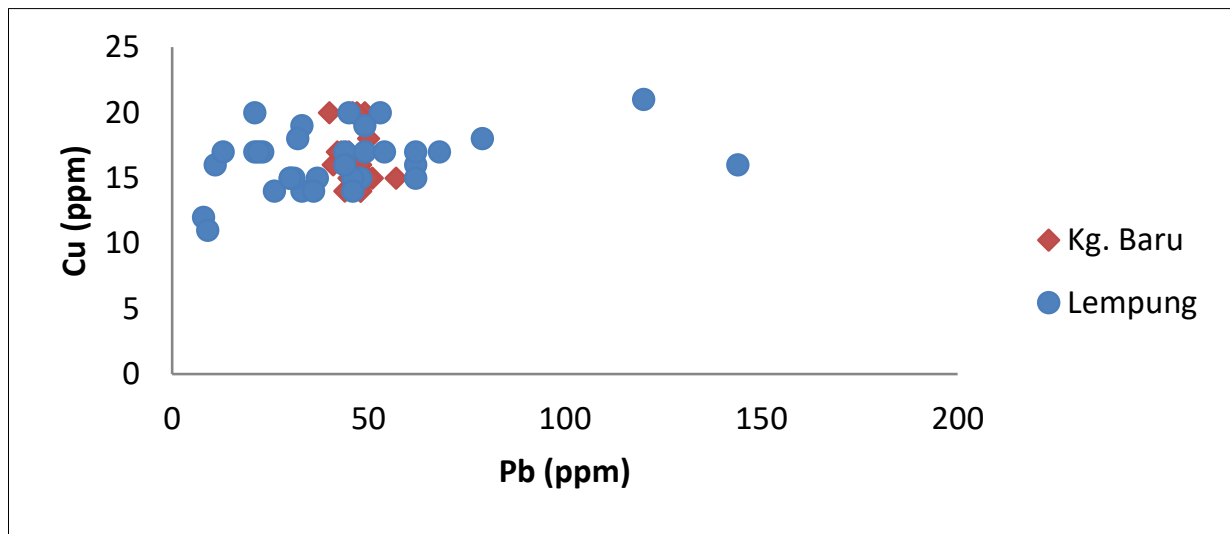

Figure 7: Scatter plot of $\mathrm{SiO} 2$ and $\mathrm{Al} 2 \mathrm{O} 3$

Table 3: Content of trace elements (ppm) in bricks sample from Candi Kampung Baru

\begin{tabular}{|c|c|c|c|c|c|c|c|c|c|c|c|c|c|c|}
\hline \multirow{2}{*}{ Sample } & \multicolumn{14}{|c|}{ ppm } \\
\hline & As & $\mathbf{B a}$ & $\mathrm{Ce}$ & $\mathrm{Cr}$ & $\mathbf{C u}$ & Ga & $\mathbf{N i}$ & $\mathbf{P b}$ & $\mathbf{R b}$ & $\mathrm{Sr}$ & Th & $\mathbf{V}$ & Zn & $\mathbf{Z r}$ \\
\hline KB 1 & 19 & 747 & 574 & 81 & 20 & 17 & 46 & 49 & 132 & 31 & 23 & 88 & 76 & 170 \\
\hline KB 2 & 16 & 696 & 584 & 100 & 14 & 27 & 26 & 48 & 66 & 9 & 24 & 125 & 45 & 332 \\
\hline KB 3 & 18 & 835 & 468 & 67 & 17 & 15 & 32 & 45 & 187 & 62 & 19 & 79 & 81 & 220 \\
\hline KB 4 & 17 & 710 & 600 & 100 & 15 & 26 & 27 & 51 & 59 & 11 & 28 & 134 & 48 & 417 \\
\hline KB 5 & 15 & 721 & 553 & 77 & 16 & 18 & 31 & 41 & 173 & 53 & 23 & 89 & 90 & 241 \\
\hline KB 6 & 17 & 818 & 566 & 81 & 20 & 19 & 39 & 46 & 192 & 53 & 24 & 89 & 105 & 278 \\
\hline KB 7 & 17 & 755 & 608 & 85 & 17 & 20 & 34 & 43 & 184 & 58 & 24 & 94 & 98 & 173 \\
\hline KB 8 & 10 & 706 & 569 & 74 & 15 & 24 & 28 & 46 & 56 & 8 & 13 & 105 & 45 & 349 \\
\hline KB 9 & 17 & 747 & 538 & 72 & 15 & 17 & 29 & 45 & 195 & 58 & 20 & 82 & 83 & 165 \\
\hline KB 10 & 14 & 768 & 599 & 80 & 17 & 18 & 29 & 42 & 171 & 44 & 22 & 88 & 64 & 189 \\
\hline KB 11 & 18 & 801 & 509 & 71 & 20 & 18 & 31 & 47 & 195 & 51 & 24 & 84 & 96 & 202 \\
\hline KB 12 & 15 & 749 & 586 & 93 & 18 & 26 & 30 & 50 & 66 & 11 & 23 & 112 & 50 & 281 \\
\hline
\end{tabular}


Zuliskandar Ramli, Muhammad Nu'man, Abdul Latif, Nor Zalina, Mohd Shamsul Bahari, Nuratikah \& Nur Sarahah XRD and XRF Analysis of the Ancient Bricks from Candi Kampung Baru, Kedah

\begin{tabular}{lllllllllllllll} 
KB 13 & 18 & 745 & 535 & 76 & 14 & 18 & 34 & 44 & 205 & 59 & 25 & 87 & 78 & 269 \\
KB 14 & 9 & 727 & 617 & 79 & 16 & 23 & 35 & 47 & 57 & 8 & 12 & 103 & 42 & 315 \\
KB 15 & 18 & 689 & 590 & 88 & 16 & 24 & 30 & 48 & 88 & 26 & 19 & 106 & 76 & 279 \\
KB 16 & 24 & 664 & 502 & 109 & 15 & 28 & 29 & 57 & 66 & 10 & 27 & 131 & 65 & 430 \\
KB 17 & 15 & 750 & 614 & 94 & 14 & 26 & 28 & 48 & 60 & 10 & 27 & 123 & 42 & 382 \\
KB 18 & 15 & 781 & 625 & 111 & 15 & 28 & 29 & 50 & 60 & 9 & 24 & 140 & 53 & 348 \\
KB 19 & 16 & 638 & 469 & 86 & 20 & 20 & 36 & 40 & 159 & 52 & 26 & 89 & 94 & 199 \\
KB 20 & 11 & 761 & 559 & 76 & 15 & 22 & 29 & 47 & 58 & 5 & 12 & 97 & 42 & 320 \\
\hline
\end{tabular}

\section{CONCLUSION}

The study on the material composition of the ancient bricks of Candi Kampung Baru shows that the bricks have an almost similar material composition as the clay in Bujang Valley, Kedah which is based on major and trace elements which are similar to compositional of clay samples. The mineral content present in the ancient brick samples consists of quartz, muscovite, and microcline. The results of the study also found that the open burning technique was used in the production of the candi's bricks because some of the bricks have an indication of low firing burning process. The dry weight percentage graph of silica and aluminium and magnesium and titanium, as well as the lead and copper concentration graph, indicate that the raw materials used to produce the ancient bricks are local raw materials and these materials were obtained from the Bujang River and Muda River Basin in Kedah. Therefore, local community was directly involved in brick making industry where the industry was the main supplier for the construction of several structure or monument made from bricks located in Old Kedah Kingdom.

\section{ACKNOWLEDGEMENT}

This study was conducted by using funding from the research projects of the DPP2015-068 and FRGS/2/2014/ STWN05/UKM/02/1.

\section{REFERENCES}

Abdullah, F. (2013). Kepelbagaian jenis seramik di Tapak Arkeologi Sungai Mas, Kota Kuala Muda Kedah (Master thesis). The National University of Malaysia, Bangi, Malaysia.

Chia, S. (1997). Prehistoric pottery sources and technology in peninsular Malaysia based on compositional and morphological studies. Malaysia Museums Journal, 33, 91-125.

Hussein, M. Z. Ramli, Z., \& Yahaya, A. (2004). Chemical physics analysis for building materials of Bangunan Panggung Drama Jalan Bandar Kuala Lumpur Malaysia: a case study. Proceedings of National Conference on Science and Technology in Conservation of National Heritage: Integration of Science, Technology and Heritage, (p. 274). Malaysia: Malaysian Institute for Nuclear Technology Research (MINT). 
Jacq-Hergoualc'h, M. (1992). La civilisation de ports-entreports du sud Kedah (Malaysia) Ve-XIVe siecle. Edition L'Harmattan, Paris.

Jusoh, A., Sauman, Y., Abdul Rahman, N. H. S. N., \& Ramli, Z. (2012). Scientific analysis of samples of some artefacts metal age in Malaysia. Social Sciences (Pakistan), 7(6), 772-777.

Mohd Nasir, M. N., Ramli, Z., \& Hassan, Z. (2017). Analysis of pottery tipology and motif at Candi Kampung Baru, Kota Kuala Muda, Kedah. Asian Journal of Environment, History and Heritage, 1(1), 281-283.

Nik Abdul Rahman, N. H. S. \& Mohd Yatim, O. (1992). Warisan Lembah Bujang. Kuala Lumpur: Ikatan Ahli Arkeologi Malaysia \& Jabatan Muzium dan Antikuiti.

Ramli, Z. (2012). Proses akulturasi budaya India dan transformasi ilmu masyarakat Kedah Tua berdasarkan data arkeologi dan kajian saintifik (Doctorate thesis). The National University of Malaysia, Bangi, Malaysia.

Ramli, Z., Abdul Rahman, N. Q., Hussin, A., Sayed Hasan, S. N. I., \& Mohamed Dali, A. (2017). Compositional analysis of Sungai Mas, Kuala Selinsing and Santubong glass beads. Mediterranean Archaeology and Archaeometry, 17(2), 117-129.

Ramli, Z. \& Nik Abdul Rahman, N. H. S. (2012). Zaman protosejarah di Malaysia. Bangi: ATMA UKM.

Ramli, Z., Nik Abdul Rahman, N. H. S, \& Samian, A. L. (2011). X-ray fluorescent analysis on Indo-Pacific glass beads from Sungai Mas archaeological sites, Kedah, Malaysia. Journal of Radioanalytical and Nuclear Chemistry, 287(3), 741-747.

Ramli, Z., Nik Abdul Rahman, N. H. S, Jusoh, A., \& Hussein, M. Z. (2012). Compositional analysis on ancient bricks from Candi Sungai Mas (Site 32/34), Bujang Valley, Kedah. American Journal of Applied Science, 9(2), 196-201.

Ramli, Z., Nik Abdul Rahman, N. H. S, Samian, A. L., Razman, M. R., Syed Zakaria, S. Z., \& Mohd Yusof, A. R. (2013). Scientific studies of Candi Pengkalan Bujang (Site 19) ancient bricks: Knowledge of Old Kedah Community's in usage of local raw materials. Research Journal of Applied Science: Engineering and Technology, 6(15), 2859-2864.

Sabtu, S. N., Mahat, R., Mohd Amin, Y., Price, D. M., \& Bradley, D. A. (2015) Thermoluminescence dating analysis at the site of an ancient brick structure at Pengkalan Bujang, Malaysia. Applied Radiation and Isotopes, 105, 182-187.

Treloar, F. E. (1978). Chemical analyses of iron, iron slag and pottery remains of the prehistoric iron industry of the Sarawak River delta. The Sarawak Museum Journal, 26(47), 126-133.

Wheatley, P. (1964). The Golden Khersonese. Kuala Lumpur: University of Malaya Press.

Yahaya, A., Hussein, Z., Ramli, Z., \& Zakaria, K. (2005). Chemical and physical analysis of a brick and adhesive available in Kota Kuala Muda, Kedah. Jurnal Arkeologi Malaysia, 18 . 